\title{
The Declining Profile of Physical Education Programme in Educational Institutions in Nigeria
}

\author{
${ }^{1}$ Isaac Olusola Akindutire (Ph.D.), ${ }^{2}$ Johnson Adetunji Olanipekun (Ph.D.) \\ ${ }^{1,2}$ Both Authors are Lecturers in the Department of Human Kinetics and Health Education, Ekiti State \\ University, Ado-Ekiti, Nigeria
}

\begin{abstract}
Since the early days of Nigerian history, Physical Education has always been considered as an integral part of educational system as obtained in several nations of the world. The awareness of the values of physical activities and sports, gave a boost to the prominence given to the practical and pedagogical aspects of physical education in all segments of educational system in Nigeria, between 1950s and 1980s. Physical Education was a compulsory subject in the curriculum of primary and teacher education, while the National Policy on Education of 1970s and 1980s accommodated the programme for secondary education. However, it is rather disturbing to note that there has been a systematic decline in the fortune of physical education in Nigerian schools since 1990 to date. This paper therefore, examines the acceptability and recognition of physical education programmes in Nigerian schools, and the inherent factors responsible for the steady decline of its profile over the years.
\end{abstract}

Keywords: Physical Education, health education, sport's programme, curriculum instruction, educational institution,

\section{Introduction}

Physical Education, as a teaching subject, has suffered neglect in Nigerian educational institutions in the past, as its scope was limited to exercises, physical drills or muscle building. In recent times, the Nigerian educators agreed that Physical Education/Human Kinetics be integrated into the school curriculum as a teaching subject. The Federal Government of Nigerian in its policy on education (National Policy on Education 1981, 2004) therefore, stressed the need to direct the quality of instruction at all levels, towards the promotion of educational, physical and psychological health of all children among others. This will enable them become functional and productive members of the society. Thus, a functional Physical Education Programme in all educational institutions must be vigorously pursued if appropriate skills, abilities and competences (both mental and physical) needed to equip the individuals to live in and contribute meaningfully to the development of the society must be achieved. It is in full realization of this assumption, that the Federal Government of Nigeria approved the inclusion of Physical and Health Education Curriculum into the educational institutions at all levels. It is rather unfortunate that there is a decline in the participation in Physical Education programme in educational institutions in Nigeria owing to many variables being discussed in this paper.

\section{Concept of Physical Education: An Overview}

Traditionally, Physical Education is viewed as integral aspect of the process of education, which aims of achieving the goals of education through the medium of physical activity experiences. It could also be viewed as the phase of education which deals with the development and adjustment of the individual through carefully selected and well conducted programme of physical activities and related experiences.

The current interpretation of Physical Education is centrally based on its conceptual meaning as a discipline of knowledge or subject-matter oriented, since all disciplines are concerned with certain aspects of human endeavour. Physical Education as a body of knowledge is viewed as an area of study concerned with human movement behaviour (Human Kinetics). Movement is a fundamental characteristic of life. This gives Physical Education a unifying focus and makes possible an identification of its knowledge structure. Thus, Physical Education is a discipline of human movement studies concerned with the study of man and his movement behaviour patterns and the variety of applications of this knowledge in the service of man and society (Ojeme, 1990).

Basically, Physical Education or Human Movement Study aims at understanding human beings from their movement characteristics, the effects or influence of movement involvement on the individual (wellness) and society, as well as the aggregate of factors which enhance or limit man's movement capabilities.

The conceptual basis of Physical Education is basically concerned with the arts and science of human movement as a discipline (Metheny, 1970; Mackenzie 1969). This enables us to understand the framework of Physical Education which includes: forms of movement; mechanical principles of movement; structure and 
functions of man in motion; movement and the person; methodological dimension of human movement (Adedeji, 1985; Ojeme, 1990 and Akindutire, 2005).

The proper execution of these modern concept of the contents of instruction in Physical Education by the effective, efficient and committed Physical Educators, would enable them to achieve their intentions and resolutions (Nwankwo, 1996 and Salami, 2003) which include:

- making individual become reasonably competent in basic movements, fundamental sports skills, and acquiring knowledge of the basic facts, principles and laws and concepts of how people move;

- identifying relationship between human movement and human functioning;

- understanding the significance and role of human movement in cultures and societies of the world and the meaning it makes in one's life;

- knowing the aesthetic dimensions of human movement form and how and why beauty in human motion can be interpreted;

- making the individual gain proficiency in a sport of one's choice; and

- interpreting the meanings of human movement to many people and why people are motivated to move in characteristic way.

\section{Past and Current Trends of Physical Education in Educational Institutions in Nigeria Primary School Physical Education}

Physical Education was being taught as an integral part of the total educational curriculum with similar goals and unique contributions. As far back as 1933, a handbook on Physical Training brought from Britain was adopted in Nigeria as Physical Education Syllabus (Ladani, 1988). The 1933 Physical Education Syllabus contained physical drills, track and field, football and netball with emphasis on the physical, health or wellness of pupils as a whole. The 1933 Physical Education Syllabus was not uniformly introduced and used in the country. Each region had its own adapted Physical Education syllabus to cater for its region because each region had its peculiar social and environmental factors (Oduyale, 1983). The 1933 syllabus was undoubtedly a major influence in the teaching of Physical Education in Nigerian schools.

However, the availability of the syllabus only made physical training a priority of the teachers and not an examinable subject in primary schools, but made it a compulsory requirement for the award of Teachers' Grade II Certificate (TC II) and for the primary school children, thus included in the school time-table, but remained teacher-centered. There were no opportunities for all categories of pupils to participate in it (Onifade, 2010). There were no opportunities for Physical Education at that time beyond the elementary schools, because of inadequate qualified Physical Education teachers and inspectors in the Ministry of Education.

Currently, Physical Education is included in the national curriculum of all educational institutions (FGN, 2004) except the Polytechnics. It is now in the school teaching time-table and compulsory at the preprimary and primary (Basic Schools) schools. The instruction in Physical Education is normally done during the morning schools periods with or without facilities and equipment. However, indoor lessons are arranged whenever it is not possible to have practical lessons because of inclement weather.

Physical Education in elementary schools covers a wide field of studies which do not limit the child only to various games and athletics, but also involves a wide range of theoretical knowledge acquisition. A well designed basic school Physical Education programme is geared towards developing total fitness, creating good learning environment and providing equal opportunity for all children to participate in games and sports. Thus, Physical Education instructions in the primary schools in Nigeria consist of class instruction in sports and games, physical fitness activities, intramural and inter-school sports for the talented athletes in the schools (Adedeji, 1985; Oyenusi and Abioye, 1983; Ajisafe, 1991 and Onifade, 2001)

\section{Secondary School Physical Education}

In the past, Physical Education was not a compulsory subject or teaching
subject. The subject was not on the school time-table since there was no government legislation requiring it at this level. The graduate teachers of Physical Education were forced to teach their second subjects such as, Biology, English, Health Science, Chemistry and others.

In some secondary schools where Physical Education was allowed, it usually took place very early in the morning before school lessons and late in the afternoon as sports and games practice session. In Government Colleges (secondary) as well as established nursing schools, they had trained Physical Education specialists assigned to teach Physical Education.

Today, Physical Education is a compulsory teaching subject in the Junior Secondary Schools as an examinable subject. It is an optional examinable subject at the Senior Secondary School, WAEC and NECO. Only Physical Education specialists, (NCE and Bachelor Degree Holders) teach the subject at the secondary school level. The choice of the subject (Physical Education) by the students at the Senior Secondary School 
level is handled by the school Counselors with shallow knowledge of the prospects of the Physical Education. It is a common practice in some schools to use Physical Education periods on the timetable for organizing Inter house sports' competitions and for gardening.

\section{Teacher Training College Physical Education}

In the past, Physical Education was a core subject for the award of Teachers' Grade III, II \& I Certificates having passed through Teachers' Training Colleges for 3 years, 2 years, and 1 year intensive education programme for primary school teachers. Physical Education activities in the Teachers' Grade II Colleges involved dance, gymnastics, soccer, netball, volleyball, badminton, tennis and hockey (Ajisafe, 1980 and Deleckey, 1985). Today, Teachers' Training Colleges had been abolished and replaced fully by Colleges of Education for NCE programme to produce Nigerian Certificate in Education teachers.

\section{Physical Education in Higher Institutions}

At the Colleges of Education and University levels, Physical Education is a discipline and profession being studied. Additionally, all Colleges of Education in Nigeria have the Department of Physical and Health Education (PHE) or Health and Physical Education (HPE), where the Nigerian Certificate in Education in PHE/HPE is awarded. Many Universities in Nigeria offer Physical Education as a course of study for the Bachelors, Masters, and Doctorate degrees.

\section{Factors Responsible for the Declining Profile of Physical Education in Schools}

Physical Education like any other disciplines in the school curriculum, has many challenges in participation towards achieving its set goals and objectives in schools. Generally, certain problems cut across all educational institutions. The abolition of Teachers Grade II Colleges in Nigeria, where foundation of Physical Education, as a discipline and course of study, was laid is identified as a determinant in the declining profile of the programme in schools in Nigeria. Physical Education facilities and equipment are expensive, thus requiring a large sum of money to procure. Unfortunately, Physical Education and sport facilities and equipment are grossly inadequate for teaching of the subject in most Nigeria educational institutions. Most institutions do not have minimum standard of facilities and equipment. Even what is available in the universities is grossly inadequate relatively. Cultural and religious taboos in some communities, inhibit children from exposing some parts of their bodies (their hand, legs and thighs) during Physical Education practical lessons. Such restrictions normally have detrimental effects on the effective participation in Physical Education.

Physical Education as a subject, is an institutionalized educational activity through the physical which requires people with specific human resources. In Nigeria, it is rather unfortunate to note that people who possess or control those resources are not found in the administrative posts, not only in the Physical Education and sport, but also in running the government of the nation.

Economic and social class, gender and tribe are interconnected, because they limit Physical Education and sports participation among students from low-income background. Opportunities to be accepted into the academic discipline were very limited for Physical Education and sports. According to Adedeji (1994 and 2001), few Physical Education specialists in the past achieved fame and fortune in sports, but because of perceived obstacles to achievement like other careers, many young specialists in contemporary society see Physical Education and sports participation as an occupation in its glorious height only.

In relation to social class, employment, economy and income, the changes that have occurred in recent years, seem to be most visible in relation to employment. Unfortunately, students' enrolment for Physical Education in the tertiary institutions in Nigeria has declined dramatically (Hendenson, 1996). The few textbooks available on Physical Education and sports written by Nigerian authors emphasise mainly games and sports skills, neglecting other aspects of the programme.

Research on occupational perspective is built on an understanding that occupation is a socio-economic construct which differs within and between economics (Hendenson, 1996 and Ojeme, 1999). This is important in relation to Physical Education and sports participation, because historically, Physical Education and sports have been looked upon as important area in which high economic values are placed. Power becomes important because the economic value order is constituted by power relations between economic and occupation. In relation to Physical Education and sports, it can be expressed that dominant forms of teaching subjects with the educational systems in the past were structured and organized in ways that worked to their advantages, but to the disadvantage of Physical Education and sports. If Physical Education has been created to fit into the dominant teaching and examinable subjects, then the occupation logic of Physical Education and sports should have been flexible.

Another problem of Physical Education in Nigerian schools is the teaching method employed by teachers. The common method of teaching Physical Education is the regimental/command type, especially in the teaching of skills courses with dictation and note taking for teaching theoretical courses. The method 
contradicts the provision of the new education policy, because students are not able to discover facts for themselves, and they are not creative and self-reliant.

Physical Education curriculum development and syllabus contents in Nigeria and in Africa compared with that of Europe and America are defective (Hendman and Marshall, 2000). Ajisafe (1997) and Kein (1999) claimed that inadequate allocation of time, modern sports facilities, lack of application of educationally sound curriculum construction methods are major constraints in the teaching and learning of Physical Education in Nigerian schools. They also expressed concern about the insufficient qualified and commitment Physical Education teachers, political instability, ethnicity, religious inclination and corruption as challenges to the status of Physical Education and sports in Africa. The Inspectors of Education (Physical Education and sports section), who are supposed to monitor the implementation of Physical Education curriculum in the primary and secondary schools do not perform their functions effectively. In many schools, Physical Education practical is not enforced, while some teachers do not teach it at all, and nobody seems to bother, in spite of the interest usually exhibited by students in the programme.

The issue of who is responsible for liabilities during Physical Education practical lesson is another factor. The safety of both the Physical Education teachers, coaches and students is very paramount to the participants and other education stakeholders. The negative attitudes of both parents and even the Physical Education teachers in terms of methodology, appearance, physical fitness, other behavioural dispositions affect students' participation in Physical Education Programme. The negative perception of non-physical Education Teachers (school-counselors) usually affect the destiny of talented Physical Education students (Eniola, 1997 and Eboh, 2003).

\section{Conclusion}

Physical Education in educational institutions in Nigeria like other subjects in the school curriculum, is faced with many problems which affect students' participation in the programme. Issues related to poor resource allocation, non-utilization of teaching time, poor implementation of curriculum, personality clashes among Physical Education leaders, social and cultural pressure against majority of women in sports, superstitions and misconceptions about human body and health, drug abuse among students and athletes are some of the factors responsible for the declining profile of Physical Education in institutions of learning in Nigeria (Oranugo, 1998).

\section{Recommendations}

Based on the identification of the declining status of Physical Education programmes in educational institutions in Nigeria, it is therefore, recommended that:

1) There should be effective funding of Physical Education programme by government and other educational stakeholders for the provision of facilities and equipment.

2) The school-village concept should be introduced in schools. This would allow for a joint provision and use of sport facilities.

3) Encouragement through financial support and recognition should be given to outstanding writers of textbooks and manuals on Physical Education and sports. Physical Education textbook writers should be commissioned.

4) There should be sufficient number of well qualified, efficient and committed Physical Education teachers. Re-training of Physical Education teachers through in-service courses, workshops, conferences and seminars would make them update their professional competence.

5) Teachers of Physical Education should be advised to employ the exploratory method of teaching, especially in the skill courses so that students can practice freely, discover for themselves, learn better and choose freely what and how they want to do things.

6) The use of electronic equipment (films slides, videos, tapes) would complement demonstration and play back teaching for class discussions as well as making it possible to see each phase of skill for better analysis and learning.

7) Public enlightenment programme should be given to educate all the stakeholders on the misconception and myths, taboos regarding participation in Physical Education and sports by students, especially women.

8) There is the need to restructure the Physical Education curriculum in Colleges of Education and Universities to give room for technical skills in field maintenance and store -keeping in sports and Physical Education. 


\section{References}

[1]. Adedeji, J. A. (2001): Equality of Opportunity: The Evolution of Democracy in Physical Education and Sports Ibadan: A Valedictory Lecture, University of Ibadan. Eden Prints.

[2]. Adedeji, J. A.(1985). Teaching of Physical and Health Education.(1st Ed). lbadan: Westbooks Publishers Limited.

[3]. Ajisafe, M. O. (1991): Physical Education in the Service of Mankind: An Epistemological Functional Survey. An inaugural Lecture delivered at the University of Benin, Benin City.

[4]. Ajisafe, M. O. (1997): Some hints on the Status of Physical Education and Sports in Africa. IGSSPE/GEPSS Bulletin, $23,24-26$.

[5]. Akindutire, I. O. (2005): Repositioning Physical Education and Sports Programmes for the Development of man 13th Inaugural Lecture (Thursday 12th May), University of Ado-Ekiti.

[6]. Eboh, L. O. (2003). Application and strategies for advancing the level of Physical Education and Sports for the African Child. Paper presented in 1st ICHPER in African Regional Conference, Lagos: University of Lagos Conference Centre: 67 - 70.

[7]. Eniola, L. (1997): Evolution of Physical and Health Education research in Nigeria (Key Note Paper II) in Igbango, V. C. (Ed): Research in Health Physical Education, Sports and Dance (Proceedings of the 10th Annual and Anniversary Conference of Nigeria Association of Sports Science and Medicine (NASSM) XXIII.

[8]. Federal Ministry of Education (1981): National Policy on Education. Lagos: Federal Government Press.

[9]. Federal Ministry of Education (2004): National and Policy on Education (4th Ed). Lagos "Federal Government Press.

[10]. Hardmon, K. \& Marshall, J. (2000): Physical Education in Schools. ICIIMYR-SD. Journal 36, 3 Summer Edition.

[11]. Henderson, S. B., (1996). Physical Education and Sports: An occupational Perspective (9th ed.). London: C.V. Mosby Company.

[12]. Keim, M. (1999): From and In-Service Training Project (INSET) to a further Diploma in Physical and Health Education (FDE)-a progress report. Paper presented at the Pre- All-African Games Congress. Johannesburg, 6 - 9 September.

[13]. Ladani, B. A. (1988): History and Development of Physical Education and Sports in Nigeria Vol. 1 Unpublished Manuscript. Ahmadu Bello University, Zaria.

[14]. Mackenzie M. H, (1969): Towards a new curriculum of physical education. New York: McGraw-Hill Book Corruption.

[15]. Metheny, E. (1970): Symbolic forms of movements: Sports and American society. Massachusetts: Addition tilesley Pub.Co.

[16]. Nwankwo, E. I. (1996): Organization and management of physical education in schools and colleges. Ibadan: Fagbamigbe Publisher Ltd.

[17]. Oduyale, A. T. (1983): Harding Expergin: The ground master of Nigerian physical education and sports Lagos; University of Lagos Press.

[18]. Ojeme, E. O. (1990). Notes on methods and materials of teaching physical education. Benin-City: Aji-rhomes Business Press.

[19]. Ojeme, E. O. (1999): The meaning and nature of physical education. American Journal of Physical Education and Sports 40.71, 5664.

[20]. Onifade, A. (1990): Prospects and Problems of Teaching Physical and Health Education under 6-3-3-4 system of education. Paper presented as the NAPHER week, Ogun State University Ago-lwoye.

[21]. Onifade, A. (2001). History of physical education in Nigeria. Lagos: Ziglag educational publishers.

[22]. Oyewusi, J. A. \& Abioye, J. A. (1983).Physical Education and sports bin Nigeria. Paper presented as the 1983 ICHPER World Congress, Nuigate Institute Natanya, Israel.

[23]. Salami, I. A. (2003). Contribution of physical education to school Sports development. Paper presented in 1st ICHPER in African regional conference, Lagos, University of Lagos conference centre. 44-46

[24]. UNESCO (1998). Chapter for Physical Education and sports. Paris: UNESCO 